\title{
FOTO
} CINEMA

\section{Sara Castrejón: fotografiar la revolución, representar a la mujer}

\section{Sara Castrejón: photographing revolution, representing women}

\section{Resumen:}

John Mraz

Instituto de Ciencias Sociales y Humanidades Benemérita Universidad Autónoma de Puebla mraz.john@gmail.com

En este artículo se presenta un análisis de la fotografía de Sara Castrejón durante la Revolución Mexicana y dentro del desarrollo de fotógrafas mexicanas. Se examina desde la fotohistoria, una vertiente de la metodología histórica en la cual las fotografías sirven de fuentes primarias. Así, el proceso es el de historia, descubrir los documentos y analizarlos desde la perspectiva de otras fuentes primarias; entre ellas, entrevistas y, además, se incorporan fuentes secundarias para contextualizar el estudio. Se pregunta cómo vivía Castrejón como fotógrafa de estudio en medio de una guerra civil y cuál era su posición política, comparada con otros fotógrafos de estudio. Además, se incorpora una perspectiva feminista al inquirir sobre cuáles eran las oportunidades para las mujeres de ganarse la vida en este periodo y cómo las decisiones de Castrejón diferían del patrón tradicional. Asimismo, se analizan particularidades de la fotografía de Castrejón que muestran cómo su género se expresó en su imaginario. Las imágenes de Castrejón se consideran un ejemplo de fotografía "vernácula", la producida fuera de los cánones del arte (Batchen, 2000). En ese sentido, se podría considerar el estudio como inspirado por la teoría fotográfica posmoderna al desplazar la fotografía de arte de su dominio discursivo.

\begin{abstract}
:
In this article an analysis is presented of Sara Castrejón's photography of the Mexican Revolution, with the development of Mexican women photographers. This is carried out through a photohistory that employs an historical methodology in which photographs serve as primary sources. Hence, the process is that of history, which is discovering primary sources, among them interviews and, moreover, incorporating secondary sources to contextualize the study. Inquiry is made into how Castrejón made a living in the midst of the civil war, and her political position as compared to that of other studio photographers. Moreover, a feminist perspective is incorporated by examining what opportunities existed for women in this period and how the choices Castrejón made differed from traditional patterns. The particularities of Castrejón's photography that derived from her gender are examined. Castrejón's imagery can be considered an example of "vernacular" photography, which is produced outside artistic canons (Batchen, 2000). In this sense, the study could be considered as being inspired by Postmodern photographic theory, which displaces art photography from its discursive dominance.
\end{abstract}

Palabras claves: Revolución Mexicana; fotografía revolucionaria; fotografía de estudio; tarjetas postales; fotografía vernácula; fotógrafas mexicanas.

Key Words: Mexican Revolution; revolutionary photography; studio photography; postcards; vernacular photography; women photographers. 
Tan excepcional como típica, Sara Castrejón fue la única mujer que documentó ampliamente la Revolución Mexicana (1910-20), una de las primeras fotógrafas de guerra del mundo y una pionera que abrió camino para las mujeres en el mundo de la imagen. ${ }^{1}$ Nacida en 1888 en la pequeña ciudad de Teloloapan, en el estado de Guerrero (que entonces, como ahora, era una de las áreas más inaccesibles de México), vivió sin embargo en un ambiente privilegiado.² Teloloapan era conocido como "la Atenas de Guerrero" por la riqueza de su vida cultural, fomentada por círculos de lectura, grupos de discusión literaria y tertulias en las que se escuchaban piezas de compositores como Schubert, Mozart y Chopin. Tanto lo remoto de su ubicación como su significación nacional pueden verse en el hecho de que fue una de las primeras ciudades mexicanas en conectarse al sistema eléctrico nacional, en 1938. Un año antes, el presidente Lázaro Cárdenas había visitado Teloloapan y había pedido que le presentaran a Sara Castrejón. El viaje de Cárdenas a Teloloapan demuestra la importancia de la ciudad, y sin duda tuvo que ver con su electrificación un año después. Su deseo de conocer a Sara indica el grado de reconocimiento cultural del que gozaba, pues se le consideraba una cronista de la ciudad con cámara.

La familia en la que Sara Castrejón creció fue relativamente acomodada, puesto que su padre era abogado y uno de sus hermanos llegó a ser joyero. Sin duda, fue una de las precursoras de la fotografía entre las mujeres en México, pues a los 18 años emprendió un viaje a la capital de la república para aprender este oficio, lo que aparentemente le tomó más de un año entre 1906 y 1907. Era inusual que una mujer entrara en esta profesión, e incluso más que partiera a la gran metrópoli para estudiar a esa tierna edad; a las muchachas privilegiadas se las enviaba a Chilapa, una ciudad guerrerense algo más grande a unos doscientos kilómetros de distancia.

\footnotetext{
1. Hasta cierto punto, me baso en las investigaciones de Samuel Villela (2010). Asimismo, agradezco a Rebeca Monroy, Paulina Michel, Carlos Córdova y Lilia Martínez la generosidad con la que me dieron información sobre la educación fotográfica de las mujeres en México.

2. El medio ambiente duro, sinuoso y montañoso de Guerrero lo mantuvo relativamente aislado hasta los años treinta, si bien la región noreste -Iguala, Chilapa y Telolapan- estaba más conectada con el resto del país. Hoy, Teloloapan es inaccesible debido a que la guerra contra el narcotráfico y la que libran los cárteles entre sí ha creado una situación de impunidad generalizada: secuestros, asesinatos, extorsión, robos y todo tipo de bandolerismo. El secuestro y desaparición de 43 estudiantes de la Normal Rural de Ayotzinapa ocurrida en Iguala, Guerrero, el 26 de septiembre de 2014 es indicativo del estado de cosas en el área. Obviamente, no haber podido ir a Teloloapan (que está a 32 kilómetros de Iguala), ni siquiera para recoger fotografías, ha limitado esta investigación. Véase Lambert (1994) respecto al aislamiento de Guerrero hasta los años noventa.
}

FOTOCINEMA, nº 22 (2021) || E-ISSN: 2172-0150 
Probablemente también era excepcional en alguna medida el volver al lugar de origen después de haber pasado tanto tiempo en la gran ciudad, pero Castrejón regresó a Teloloapan para ganarse la vida como fotógrafa de estudio. Cuando estalló la Revolución Mexicana y la gente de recursos huyó del área, ella decidió quedarse y fotografiar a las distintas facciones a su paso por la ciudad y sus alrededores. Como afirmó el sobrino de Castrejón, el historiador Francisco Nájera Castrejón (2012),

Muchas personas de dinero, muchas personas que pudieron hacerlo, se fueron de aquí y no querían saber nada de los pronunciados, las fuerzas federales, los enfrentamientos y todas esas cosas que trajo la revolución. A ella le dijeron que si se quería ir a otro lado, y dijo que no, 'Yo me quiero quedar aquí y voy a trabajar sobre este movimiento'. 3

Aunque aún queda por hacer mucha investigación en los archivos fotográficos regionales, los estudios recientes de la fotografía de la Revolución Mexicana indican que la imaginería de esa lucha procede fundamentalmente de los fotógrafos de estudio provinciales, y no tanto de los fotoperiodistas de la ciudad de México u otras grandes ciudades (Mraz, 2012, p. 4; Mraz, en prensa; Villela, 2010; Robledo Martínez, 2014).4 Es probable que toda ciudad pequeña tuviera al menos un fotógrafo de estudio -especialmente si era un centro cultural como Teloloapan, Guerrero-, que además solían viajar a los pueblos cercanos para tomar retratos. En las ciudades grandes como Guadalajara, Puebla, Monterrey y Veracruz, había varios fotógrafos de estudio, lo que da la impresión de que durante la revolución había cientos de fotógrafos de estudio trabajando en México. En el transcurso de la revolución, muchos fotógrafos de estudio se volvieron fotoperiodistas, algunos se hicieron "corresponsales" de la prensa ilustrada de la Ciudad de México (Robledo Martínez, 2014) y unos cuantos fotógrafos de estudio se unieron directamente a las distintas facciones. Muchas imágenes de fotógrafos comprometidos y “corresponsales" forman parte del célebre Archivo Casasola, junto con imágenes captadas por diversos fotoperiodistas, lo que ha creado la impresión de que las

3. Los pronunciados fueron los rebeldes que se habían pronunciado en favor de la reforma agraria.

4. La única cobertura extensa por parte de fotoperiodistas de la ciudad de México tuvo lugar durante la Decena Trágica, cuando Victoriano Huerta derrocó al gobierno de Madero, entre el 9 y el 19 de febrero de 1913. La extraordinaria producción de fotohistorias durante el Centenario de la Revolución Mexicana en el periodo de 2008-2016 ha cambiado el panorama de una manera significante. 
fotografías de esta colección son la esencia del registro documental de la Revolución. 5 Conforme se vayan conociendo más archivos regionales, se irá haciendo más evidente que los fotógrafos de estudio de provincia tomaron más fotos que los fotoperiodistas, incluso si se limitaban a cubrir las distintas fuerzas que pasaban por sus ciudades. En este sentido, Castrejón fue un personaje típico del momento, aunque algunas de sus imágenes son distintas de las que captaban los fotógrafos hombres. ${ }^{6}$

Castrejón era una persona religiosa que llevaba una vida tradicional en una ciudad provinciana. Había sido educada en una escuela para niñas en las actividades que se asignaba a las mujeres en provincia: bordar y hacer flores artificiales, velas, vinos frutales y conservas. Una vez que estableció su estudio en 1908 se dedicó casi exclusivamente a la fotografía. Vivió toda la vida con su hermana, Dorotea, que la asistía en su estudio, al igual que su hermano Joaquín, que le cargaba el equipo cuando debía fotografiar en otros sitios; era un negocio familiar mexicano bastante clásico. Las dos mujeres también se sostenían con actividades artesanales, produciendo con frecuencia alimentos como chocolate, queso y mole. Después de la revolución, Sara y Dorotea fundaron la primera sala de cine en Teloloapan. Nunca se casaron y, como comentó Eli Bartra (1996, p. 96) respecto a otra pionera de la fotografía mexicana, Natalia Baquedano, "es una mujer sin hijos y sin marido y es probable que eso tenga algo que ver con el hecho de que pueda dedicarse a una profesión en el campo del arte”. Al igual que Baquedano, Castrejón incorporó a su hermana en muchas de sus imágenes.

\footnotetext{
5. Es evidente que el estudio de la fotografía de la Revolución Mexicana se ha visto sesgado por el peso de los miles de imágenes fotoperiodísticas que contiene el Archivo Casasola de la Fototeca Nacional. Hasta 2010, solía creerse que Agustín Víctor Casasola era "el fotógrafo por antonomasia de la Revolución" (Gautreau, 2007, p. 115). Creo que mi monografía fue la primera en criticar sistemáticamente el mito de los Casasola (Mraz, 2010, pp. 49-56).

6. También es importante señalar que se conoce un número muy limitado de imágenes de Castrejón. Dado que no tuvo descendencia, la mayor parte de sus fotos y negativos desapareció tras su muerte, y es probable que muchas terminaran en la basura. Las postales que se muestran en este texto proceden sobre todo de un regalo de bodas que Castrejón hizo a su sobrina nieta Consuelo Castrejón, cuyo marido, Enrique del Rayo, era un periodista que, como Sara bien sabía, podía dar a conocer su legado fotográfico. Él insistió en que las fotos no se vendieran a coleccionistas dispersos, sino que se conservaran para estudios y exposiciones.
} 
La participación de las mujeres mexicanas en la fotografía se ha ido haciendo cada vez más visible. Ya en 1871, el gobierno de Benito Juárez (1858-72) estableció en la ciudad de México la Escuela Nacional de Artes y Oficios para Señoritas, en la que se podían tomar clases de fotografía (García Krinsky, 2012, p. 13). Es evidente que las mujeres participaron desde el principio en las exposiciones de fotografía de la escuela, ya que Margarita Henry, Galdina Melgosa y Vicenta Salazar expusieron su obra en 1873 y 1874 (Debroise, 1994, p. 31; Rodríguez, 2012, p. 25). Además, la educación fotográfica de las mujeres no se limitaba a la ciudad de México; en el periodo que va de 1893 a 1902, la Escuela de Artes y Oficios del estado de Puebla ofrecía en la capital del estado un curso de cuatro años (Martínez, 2000, pp. 32-33). La extensa lista de materias que se debían aprobar en la escuela de Puebla deja claro que las mujeres pasaban por una instrucción rigurosa en la tecnología fotográfica más avanzada del momento. Aunque conocemos los nombres de algunas de las estudiantes que pasaron por las escuelas de las ciudades de México y Puebla, nada sabemos de su obra posterior. Sin embargo, para 1900 ya había al menos treinta mujeres practicando la fotografía en el país, de las cuales cuatro operaban en la ciudad de México (Bartra, 1996, p. 221). Y si bien otras instituciones ofrecían clases de fotografía - por ejemplo, la famosa Academia de San Carlos de arte, que se había establecido a finales del siglo XVIII-, la educación fotográfica probablemente tenía lugar en los estudios más que en las escuelas.

El Taller de Fotografía de Torres Hermanos es uno de los casos documentados de educación de las mujeres en los estudios fotográficos de la época.7 En 1899, el periódico de la ciudad de México El Mundo publicó un artículo sobre este taller, señalando que "los señores Torres han sido los pioneros que en nuestro país implantaron tan feliz innovación, con la que ganan no solo las favorecidas con esos empleos, sino el público y principalmente las damas”. El artículo proseguía:

En efecto, si hay ocupación propia para la mujer, es la fotografía. Tiene aptitudes y habilidad manual extraordinarias, y sobre todo pueden servir mejor que un hombre a las damas que se retratan, arreglado ellas mismas su tocado, dándole la posición

7. Una fotografía del estudio muestra a tres mujeres, evidentemente Victoria Torres y sus hermanas, así que su participación podría haber sido más importante que la de sus hermanos (Monroy Nasr, 2015, pp. 14-15). 
propia con una confianza y minuciosidad imposibles en personas de distinto sexo (citado en Debroise, 1994, p. 36).

Parece que en 1896 se ofrecían a las mujeres lecciones de fotografía a domicilio, a juzgar por los anuncios que aparecían en los diarios de la ciudad de México (Córdova, 2014). Además, ya en 1900, había mujeres en las ciudades de Tlaxacala y Acatlán ofreciéndose a ir a fotografiar familias a sus hogares (Martínez, 2015, pp. 34-37). En Chilpancingo, las hijas de Amando Salmerón -Iris, Evita y Estela- siguieron el camino característicamente mexicano de trabajar en el estudio de su padre. Tras la muerte de Amando en 1951, fue Evita quien se hizo cargo de su estudio; mientras que Iris y Estela terminaron por establecer su propio estudio en los años sesenta y setenta (Jiménez y Villa, 1998, p. 187).

Aún no sabemos en qué lugar de la Ciudad de México aprendió Castrejón fotografía. Francisco Nájera Castrejón (2012) dice que fue en una escuela, pagada por sus padres. Sin embargo, no hay registro de que se haya inscrito en la Escuela Nacional de Artes y Oficios para Señoritas ni en la Academia de San Carlos. Cabría imaginar que antes de salir de Teloloapan hubiera contactado con algún estudio o institución, a la manera típica mexicana, a través de un pariente lejano, un amigo de la familia o la iglesia. El recorrido a la ciudad de México era formidable. Primero tuvo que viajar de quince a veinte horas en mula, por terrenos escarpados, para llegar a Iguala y tomar el tren, en el que tendría que pasar cerca de 18 horas. No se han encontrado fotografías captadas durante su estancia en la Ciudad de México.

La primera fotografía fechada de Castrejón es un retrato de 1908 de Florencio Salgado, quien, según Nájera Castrejón (1997, p. 15), era un hacendado y un cacique. Salgado también era un empresario que fundó varias fábricas en Teloloapan (de aceite de cocina, de pasta, de alcohol de caña y de agua embotellada), así como tiendas en las que se vendían diversas mercancías (Villela, 2010, pp. 24-30). Formaba parte de esa creciente clase media que Porfirio Díaz mantenía excluida del poder local al nombrar forasteros en las plazas importantes. Ésta era una vieja queja de los guerrerenses, y la misma clase que la política económica porfiriana impulsó cumpliría una parte importante en la caída de la dictadura de Díaz (Jacobs, 1982; Guzmán Urióstgui, 2002, p. 112; Knight, vol. 1, 1990, p. 307). 
Entre las fotos que Castrejón hizo durante Porfiriato, las más notables son las muchas imágenes que captó de grupos de mujeres en la Tecampana, una estructura rocosa en el campo, cerca de Teloloapan, a donde la gente se dirigía para sus excursiones y días de campo. Compuesta por la palabra náhuatl tetl (roca) y la palabra española campana, tecampana significa "campana de roca" o "la roca que suena como campana”, y se refiere a un sonido inusual que hacen las rocas cuando son golpeadas. La Tecampana es un rasgo fundamental de la identidad de Teloloapan; como expresó uno de los bardos de la ciudad, "esa es mi Tecampana sonora, símbolo de los teloloapenses, todos somos tecampaneros" (Eusebio Martínez Salgado, citado en Villela, 2010, p. 44). No sabemos por qué las mujeres se reunieron ahí y pidieron a Castrejón que las fotografiara, pero ella usó la oportunidad para situar lo "femenino" como un elemento fundamental de lo que significa ser teloloapense. Al fotografiarla desde arriba, parece "enraizarlas" en la Tecampana, como si florecieran de la fuente de la teloloapanidad. Si bien la Tecampana llevaba mucho tiempo siendo un sitio de reunión tradicional, Castrejón fue la primera en tomar fotografías ahí y, por lo tanto, esencialmente creó la identidad visual que asoció el poder mítico de ese lugar y otros sitios montañosos en torno a la ciudad, con las mujeres de Teloloapan.

Castrejón vivía de hacer retratos tanto dentro como fuera de su estudio. Según parece, solía montar escenas para enfatizar el ambiente rural y el paisaje rocoso. Las muchas postales que tomó debieron ser una importante fuente de ingresos, incluyendo la única postal conocida de Guerrero en celebrar el Centenario de la Independencia de México en 1910. Hacia el final del siglo XIX, las postales con fotos se volvieron una de esas modas pasajeras, pero inmensamente populares, tan características de la moderna cultura visual. Previamente desdeñadas por la clase "elegante y refinada" de México, las postales se volvieron artículos coleccionables y buscarlas fue una manía transitoria (Tarjetas postales, 1903, p. 13). Pronto los álbumes especiales para postales se hicieron comunes en los salones familiares. El mero número de postales enviadas por correo basta para indicar su popularidad: la Oficina de Correos estadounidense entregó casi siete millones de postales en 1908 y para 1913 ya eran casi mil millones (Vanderwood y Samparano, 1998, pp. 6-7). 
La primera postal publicada en México, en 1882, traía la imagen de Benito Juárez, y los temas nacionalistas parecen haber sido un género recurrente (Fernández Tejedo, 1994, p. 14). Sin embargo, durante el Porfiriato, el grueso de las postales parece haberse enfocado en las vistas típicas de la naturaleza, edificaciones y monumentos, así como en la representación de grupos marginales, que solían retratarse en un estilo costumbrista; es decir, "con especial interés en la descripción de la vida cotidiana por medio de personajes pintorescos y escenas folklóricas" (Fernández Tejedo, 1994, p. 39). Aunque no disponemos de cifras precisas de su circulación, las postales se vendían en México en todas partes: en tiendas departamentales y hoteles, en las tabaquerías y las taquillas de los teatros, en las corridas de toros y en los establecimientos turísticos, como la Iturbide Curio Store, la Aztec Store, y la Sonora News Company. Quizá sus mayores ventas eran a aquellos que aparecían en las postales (Fernández Tejedo, 1994, p. 14; del Castillo, 2005, p. 67). La Revolución Mexicana transformaría fundamentalmente las imágenes de postales en México, dado que los fotógrafos -tanto los de estudio como los fotoperiodistas-imprimían la mayor parte de sus fotos en ese formato. Castrejón no fue la excepción, y la mayoría de sus fotografías existentes están en postales.

La Revolución Mexicana fue el primer gran levantamiento social del siglo XX. Comenzó con una rebelión fomentada por un rico hacendado del norte, Francisco I. Madero. Entre los maderistas había otros miembros de la burguesía que se sentían excluidos del poder por la dictadura de 35 años de Porfirio Díaz. El suyo era un movimiento político que no buscaba sino un cambio de régimen. Sin embargo, una vez que la revuelta empezó, las grandes masas oprimidas de México se alzaron bajo la dirección de revolucionarios agrarios como Emiliano Zapata, Pancho Villa, Domingo Arenas y Jesús Salgado, así como fuerzas dirigidas por generales de clase media como Venustiano Carranza y Álvaro Obregón. Según se dice, cuando Díaz partió al exilio en París, comentó: "Madero ha soltado el tigre, a ver si puede domarlo" (Meyer y Sherman, 1987, p. 511). De hecho, Madero fue incapaz de contener el remolino que había creado: las fuerzas agrarias se negaron a aceptar su limitado programa social y siguieron luchando, ahora contra el propio Madero. 
En 1913, su comandante militar, Victoriano Huerta, derrocó al democráticamente electo Madero (con la complicidad del embajador estadounidense, Henry Lane Wilson). El golpe de estado fue inaceptable para todos los que se habían alzado contra la dictadura de Díaz y los llevó a hacer causa común hasta que Huerta finalmente fue expulsado del poder en julio de 1914. Una vez que Huerta se hubo ido, la verdadera revolución empezó conforme las fuerzas de Villa y Zapata combatieron a los ejércitos constitucionalistas de Carranza y Obregón. Los constitucionalistas tenían más dinero, mejor entrenamiento y el apoyo de las clases altas y medias del país, así como de la población -y la prensa- de la Ciudad de México. También se beneficiaron de los embargos que el gobierno estadounidense impuso a los villistas y zapatistas, y recibieron armas de EE.UU. Como ha argumentado el historiador John Mason Hart (1987, p. 283), las medidas de Woodrow Wilson "determinaron en buena medida quién salió victorioso de la Revolución Mexicana.” Después de 1915, los constitucionalistas desgastaron a las fuerzas radicales Villa y Zapata y para 1917 era evidente que habían vencido. Domingo Arenas fue asesinado en 1917; Zapata, en 1919; Salgado, en 1920; y Villa se rindió ese último año.

La revolución desató unas posibilidades fotográficas hasta entonces inimaginables. Históricamente, ¿̇ue éste el conflicto del que se tomaron y se conservan más fotos? La respuesta es compleja, pero podemos asegurar que la fotografía de la Revolución Mexicana es probablemente de la que se han conservado más imágenes y, sin duda, la más estudiada. Cuando emprendí la tarea de proporcionar una visión general de las obras publicadas en torno al Centenario en 2010, idescubrí que los libros apilados llegaban a más de un metro de alto (Mraz, en prensa)! Se podría haber tomado más fotos durante la revolución y la lucha anticolonial de Vietnam, pero también es cierto que ese proceso abarcó un periodo sumamente largo (1848-1975). La Revolución Mexicana fue un conflicto más largo y más amplio que la Revolución Cubana (195359) o la revolución sandinista de Nicaragua (1960s-79) y, por diversas razones, atrajo a un extraordinario número de fotógrafos, tanto nacionales como extranjeros. Por ejemplo, durante la Primera Guerra Mundial, los mandos se resistían a tener fotógrafos cerca (Moeller, 1989, pp. 109-125). En cambio, los caudillos mexicanos eran muy conscientes de la importancia de los medios modernos y recibían bien a 
los fotógrafos que cubrieron la larga guerra civil. La guerra también permitió a los fotógrafos usar su arte y sus capacidades para expresarse, así como hacer que alguien pagara su material y su equipo. Hay una diferencia fundamental entre los que escriben y los que fotografían: expresarse en imágenes técnicas cuesta dinero; los fotógrafos deben pagar por su equipo, que incluye cámaras, trípode, rollo y químicos, así como a sus asistentes.

Respecto a la imaginería predigital, siempre debemos preguntarnos: ¿Por qué se tomó esta foto? Podríamos parafrasear la famosa pregunta de Jean-Paul Sartre (1949, pp. 67-169) respecto a la escritura y preguntar: “¿Para quién fotografía uno?” El modo más directo de demostrar compromiso y percibir un sueldo era ser subsidiado por un caudillo; obviamente, quienes podían pagar por armas, municiones y uniformes también podían pagar fotografía. ${ }^{8}$ Sin embargo, había otros modos de ganarse la vida con las imágenes y, quizá, de expresar un punto de vista: trabajar para las revistas ilustradas o agencias de noticias, poseer un estudio fotográfico o un negocio de películas, o ser empleado de una institución interesada en documentar la guerra, como la Cruz Blanca Nacional. También se podía vender postales a las publicaciones, a las tiendas o a la gente que aparecía en ellas, como recuerdos.

Creo que los modos predominantes en que los fotógrafos se ganaban la vida en México eran ser dueños de un estudio por los que pasaban los ejércitos contendientes -como era el caso de Castrejón-, dejar sus estudios para alinearse con alguna facción o vender imágenes a la prensa ilustrada metropolitana. Entre los fotógrafos de estudio que documentaron la guerra, varios estaban comprometidos con grupos específicos (Mraz, 2010, 2012). Por ejemplo, la agencia metropolitana de Heliodoro J. Gutiérrez se vinculó al movimiento maderista tanto en la frontera norte como en la Ciudad de México, convirtiéndose en el primer protagonista fotográfico en el bando de los revolucionarios. Gerónimo Hernández dejó su estudio para trabajar como fotoperiodista en el periódico maderista, Nueva Era. El fotógrafo más involucrado con la rebelión de Pascual Orozco contra Madero en 1912 parece haber

8. Martín Luis Guzmán (1978, p. 338) se refirió al "agosto de los fotógrafos”, las cantidades de dinero que podían hacerse tomándole fotos a Carranza. 
sido “El Gran Lente”, Ignacio Medrano Chávez, quien tenía el estudio fotográfico de más renombre en Chihuahua. Amando Salmerón de Chilapa, Guerrero, se hizo el fotógrafo más cercano a Emiliano Zapata, aunque hubo otros vinculados a su movimiento, como Cruz Sánchez, fotógrafo de Yautepec, Morelos. Un fotógrafo de la ciudad de Puebla, apellido Hernández, parece haber trabajado para Domingo Arenas, un revolucionario agrario de esa región. Los hermanos Cachú, Antonio y Juan, tuvieron un estudio itinerante en el estado de Michoacán, pero se volvieron los fotógrafos más próximos a Pancho Villa. El movimiento constitucionalista de Venustiano Carranza y Álvaro Obregón tenía varios creadores de imágenes, pero Jesús H. Abitia de Hermosillo, Sonora, llegó a ser conocido como "el Fotógrafo Constitucionalista”. Eulalio Robles de Zacatecas fue maderista desde el principio de la lucha y pudo haber fungido como "espía de los revolucionarios", documentando el ejército de Huerta en su ciudad, su distribución geográfica, su condición, la ubicación de la artillería y sus características (Robledo Martínez, 2014, pp. 107-108). Aunque tomaban fotos para facciones que combatían entre sí, lo que todos estos fotógrafos tenían en común era que eran artistas de estudio que se convirtieron en fotógrafos callejeros y, además, son "fotógrafos revolucionarios" por sus compromisos con las fuerzas que contaban con genuinas movilizaciones populares.

Aunque las mujeres estaban en todas partes en sus funciones de soldaderas, enfermeras, oficiales y soldados comunes, Castrejón fue una de las pocas en participar con la cámara. Sin embargo, no fue la primera mujer en fotografiar una zona de guerra, un honor que aparentemente corresponde a la fotoperiodista española Sabina Muchart Collboni, que cubrió la guerra anticolonial contra España en Marruecos en 1893 (González, 2016). Otro antecedente fue Clara Chatfield Ott, una enfermera de las tropas estadounidenses en la guerra de Cuba de 1898, que tomó algunos retratos estando en la isla (Notices, OHS Research Library, 2007, p. 157). Sadie Kneller Miller también estuvo entre las primeras fotógrafas profesionales en retratar la guerra, pues documentó como fotoperiodista la larga lucha de las tropas moriscas contra el imperialismo en Marruecos en 1909 (Sadie Kneller Miller, 2015). Dos mujeres estadounidenses, Esther Eva Strauss y Clara Goodman, cruzaron la frontera para cubrir el levantamiento maderista en abril y mayo de 1911. Strauss, una 
profesional que trabajaba en el estudio de Fred Feldman, captó imágenes que aportan una perspectiva femenina de la lucha, ya sea de mujeres posando en lo que se convertiría en un tropo clásico del maderismo -sosteniendo una carabina y envueltas en cananas- o de mujeres expresando dolor espontáneamente al recibir los cuerpos de sus muertos (Berumen, 2005, pp. 161 y 215). Goodman, una fotógrafa amateur que se encontraba de visita en El Paso, cruzó la frontera para fotografiar el campamento maderista y el centro de Ciudad Juárez. La experiencia de Goodman no fue atípica: muchas de las imágenes de la rebelión en la frontera que se encuentran en álbumes familiares son obra de mujeres (Berumen, 2005, p. 157). Una alemana, Johanne Caroline Wehmeyer Bose, fotografió la entrada de las tropas maderistas a Durango, a finales de mayo de 1911 (Rodríguez, 2012, p. 173). Las hermanas Adriana y Dolores Ehlers venían de una familia antiporfirista y fotografiaron a Carranza en Veracruz (Mraz, 2010, pp. 193).

La primera imagen que Castrejón captó de la revolución -que también es la primera foto que se conserva de la insurrección en el sur- fue la de la entrada de las tropas maderistas-salgadistas en Teloloapan el 26 de abril de 1911 (F1). Estas tropas estaban dirigidas por dos comandantes. Uno era Leovigildo Álvarez, que seguiría formando parte de la rebelión maderista moderada. El otro era Jesús H. Salgado, un ranchero de clase media con intereses en la minería, al que un historiador conservador describe como un hombre de "posibilidades económicas e ideas de libertad", pero que sin embargo sería un agrarista del tipo de Emiliano Zapata, y uno de los signatarios de ese Plan de Ayala (López Victoria, 1985, p. 68; Jacobs, 1982, p. 89; Knight, 1990, vol. 2, p. 61). La clase de los rancheros -pequeños propietarios de "campos cuidadosamente cultivados [a diferencia de] los latifundios descuidados e improductivos"- fue una de las fuerzas fundamentales de la revolución en Guerrero, y la mayoría -incluyendo a la extensa familia Figueroa - terminaron por darle la espalda al agrarismo radical de los zapatistas. Sin embargo, Salgado siguió luchando por los ideales agraristas hasta que fue asesinado en 1920 (Jacobs, 1982, p. xxi). La foto se tomó desde una azotea, quizá de la casa-estudio de Castrejón, y muestra una columna de jinetes que se alargan hasta perderse en la distancia. 
Un aspecto fascinante de esta imagen es que los jinetes -especialmente, los más próximos a la cámara- parecen moverse porque están borrosos. Más que por una decisión consciente, la foto probablemente salió así porque Castejón dio a su cámara una velocidad insuficiente o no le abrió bastante la apertura, de manera que otra foto tomada un instante después también sale borrosa y en ambas parece que faltó luz. Así, probablemente no deberíamos considerar intencional por parte de Castrejón el haberle dado movimiento al encuadre, una de las estrategias definitorias de la estética del fotoperiodismo moderno, como podemos ver en el conocido (y probablemente apócrifo) dicho de Robert Capa: "Si quieres hacer una buena toma de acción, no debería estar bien enfocada. Si la mano te tiembla un poco, tendrás una buena toma de acción". 9 Esta estética del fotoperiodismo moderno se compone de varios elementos: las fotografías son espontáneas y no posadas, son captadas en medio de la acción con cámaras pequeñas que permiten a los fotógrafos acercarse sin exponerse al fuego enemigo, y las imágenes suelen incluir movimiento en el encuadre, ya sea porque el movimiento realmente ocurrió o porque el fotógrafo movió la cámara ligeramente o dejó abierto el diafragma más tiempo del necesario.

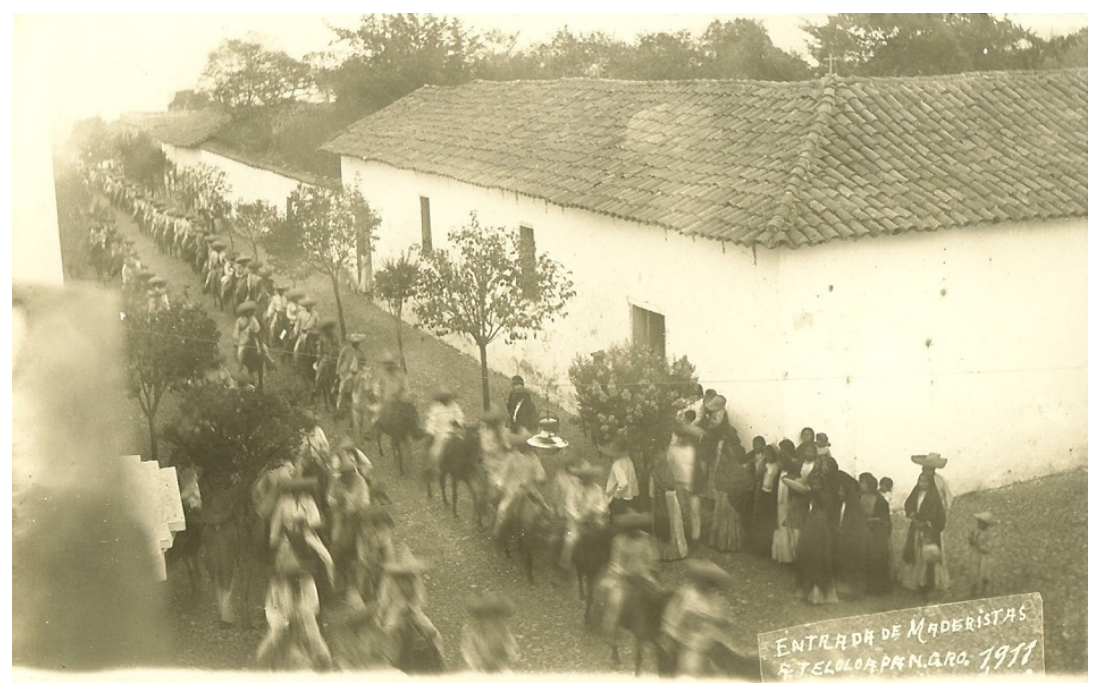

F1. Sara Castrejón. Tropas maderistas-salgadistas bajo el comando de Jesús H. Salgado entran a Teloloapan, 26 de abril de 1911. Cortesía de Consuelo Castrejón.

9. Así lo recordó O. D. Gallagher, un periodista que afirmaba haber compartido cuarto con Capa cuando tomó su famosa foto Miliciano en su momento de muerte (citado en Knightly, 1975, p. 212). 
Jimmy Hare cubrió la guerra hispanoamericana de Cuba (1898), la guerra rusojaponesa (1905) y la Revolución Mexicana; posiblemente, es el primer fotoperiodista moderno del mundo. En su introducción a la biografía que Cecil Carnes escribió sobre él, Hare alude a esa espontaneidad de las imágenes: "Quiero subrayar aquí el hecho de que lo que intenté fue obtener fotos de la acción en los primeros tiempos de la fotografía de guerra, y no sólo escenas estáticas de grupos" (Hare, 1940, p. viii). Obviamente, el fotoperiodismo moderno requiere acceso al frente de batalla: la censura que ejercían todos los ejércitos en la Primera Guerra Mundial impedía captar fotos como las que Hare pudo tomar en Cuba y México. Hare fabricaba sus propias cámaras pequeñas y ya en 1898 había empezado a incluir movimiento en el encuadre, pero su estilo se hizo más notable en sus fotos de la frontera norte de México (Gould y Greffe, 1977, pp. 24-27). ${ }^{10}$

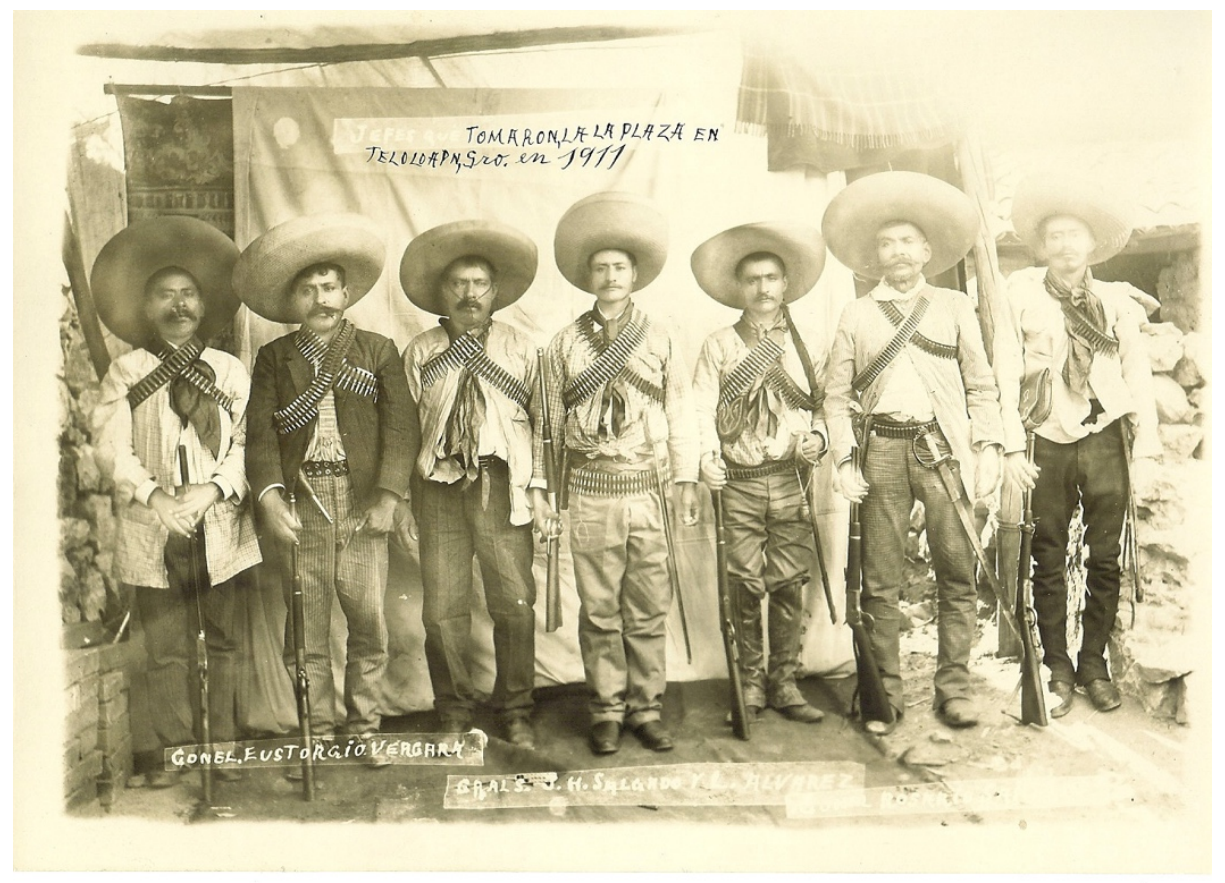

F2. Sara Castrejón. Líderes de las tropas maderistas-salgadistas, tomada en la estudiocasa de Castrejón, Teloloapan, 26 de abril de 1911. De la izquierda a la derecha: No identificado; Eustorgio Vergara; Jesús H. Salgado; Leovigildo Álvarez; Rosario Santana; Procopia Guzmán; Benigno Reyna. Cortesía de Consuelo Castrejón

10. Las imágenes de la Revolución Mexicana mencionadas pueden verse en el Harry Ransom Research Center, University of Texas, James H. Hare Collection, 1343; 1310. Agradezco al Harry Ransom Center por concederme una beca de investigación para investigar a Jimmy Hare (David Douglas Duncan Endowment for Photojournalism/Andrew W. Mellon Foundation Research Fellowship Endowment, Harry Ransom Center, University of Texas, 2013). 
Castrejón utilizó su experiencia fotografiando en el campo para registrar el campamento maderista en las afueras de Teloloapan y para captar la escala de sus operaciones como pocos fotógrafos pudieron hacerlo, incluso fuera de México. ${ }^{11}$ Una vez que las tropas maderistas-salgadistas se vieron firmemente en posesión de Teloloapan, fotografió a los oficiales y soldados posando en la calle frente a su casaestudio. A los principales líderes los llevó al jardín interior para fotografiarlos delante de un telón liso del tipo que los fotógrafos de estudio usaban en su época (F2). Castrejón instaló un mecanismo que le permitía cambiar de fondo (la orilla de otro telón puede verse a la izquierda, detrás del que está desplegado) y construyó una especie de carpa con los lados y el techo de tela para difuminar la luz de los retratos.

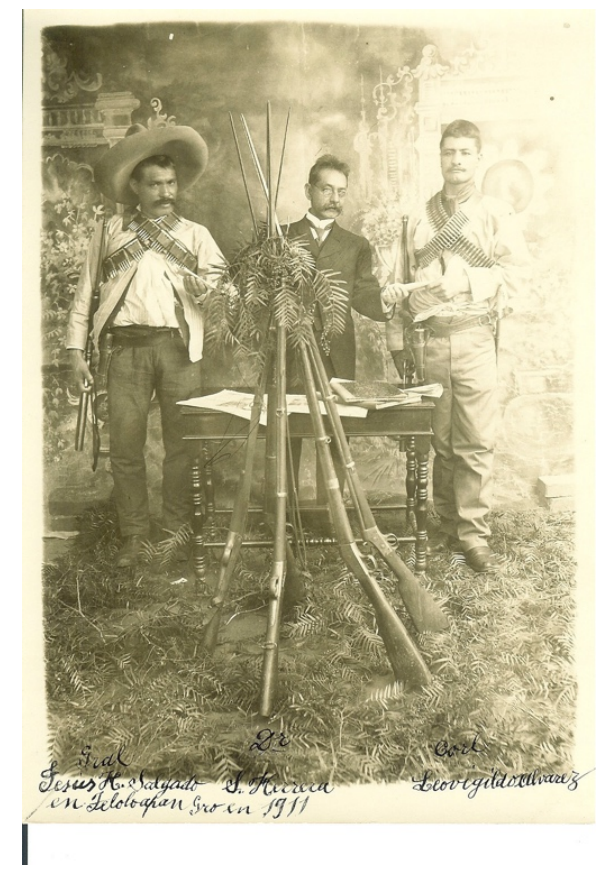

F3. Sara Castrejón. Jesús H. Salgado y Leovigildo Álvarez se reunen con el Dr. S. Herrera para recolectar fondos para la causa maderista-salgadista, Teloloapan, abril de 1911. Salgado parece tener un cheque en su mano, mientras Herrera está pasando otro a Álvarez. Cortesía de Consuelo Castrejón.

En este momento, aunque no el mismo día (Salgado y Álvarez llevan ropa distinta), Castrejón colaboró con los dos líderes montando una escena en la que se representaba al Dr. Severo Herrera García donando dinero a la causa revolucionaria

11. Jane Carmichael (1989, p. 70) señala sobre la imaginería de la Primera Guerra Mundial que "una de las críticas frecuentes a la fotografía oficial era que no trasmitía la escala colosal de las operaciones". 
(F3). En la foto, Salgado y Álvarez aparecen recibiendo documentos o cheques de manos de Herrera García en apoyo a sus fuerzas. Quizá Salgado ya había empezado a dirigir el movimiento, porque se le identifica como "General" mientras que a Álvarez, que ya tenía ese rango, se le llama "Coronel". El fondo es una curiosa combinación de rifles con las bayonetas caladas, que probablemente pertenecieron al ejército porfiriano, sobre un suelo arreglado con ramas de un árbol de pimienta, que también coronan los rifles. Es una escena extraña, que de algún modo se refiere a la guerra, a la naturaleza y a cierta autenticidad legal, simbolizada por la mesa, los documentos y el traje del doctor.

Dorotea Castrejón pintaba los telones de fondo y uno de ellos aparece frecuentemente en las fotos del estudio de Sara. En la foto de la coronel salgadista Amparo Salgado, el fondo aporta un juego visual intrigante con los motivos florales de su vestido $(\mathrm{F} 4)$. Debe notarse que Salgado eligió ese vestido (o Sara lo eligió para ella), porque Lucila Figueroa, una dama profundamente conservadora y antizapatista de la clase alta de Teloloapan -y parte del clan Figueroa- describió a la coronel con estas palabras: "Era una loca que andaba con los hombres, era Coronela... andaba con los hombres, armada, y se vestía con pantalones como los hombres" (Figueroa, 2004). ¿Acaso el vestido fino, el sombrero elegante y los zapatos en punta (quizá de tacón) eran un modo de enfatizar el género de Salgado? Si era así, la carabina, la pistola y las cananas contrastan fuertemente con la feminidad del atuendo. Lucila Figueroa había nacido en 1910 y debía de haber obtenido su información de segunda mano, pero el suyo es el único testimonio con el que contamos para presentar a Amparo Salgado.

La coronel era hermana de Timoteo Salgado, dueño de una planta eléctrica, una pequeña industria local, así que venía de la clase media-alta (Figueroa, 2004). Su decisión de juntarse con la rebelión marcó una ruptura severa con su familia y fue desheredada; salió de Guerrero y eventualmente murió en Michoacán, pero no se conoce la causa de su muerte (Ocampo M., 2018). Participó activamente en la lucha conduciendo a hombres y mujeres en el combate, así que las armas que aparecen en la foto no eran simple decorado, como ocurría con frecuencia con el tropo 
performático de las "mujeres con cananas" de la frontera norte que la historiadora Gabriela Cano (2010, pp. 98-99) asocia con el movimiento maderista.

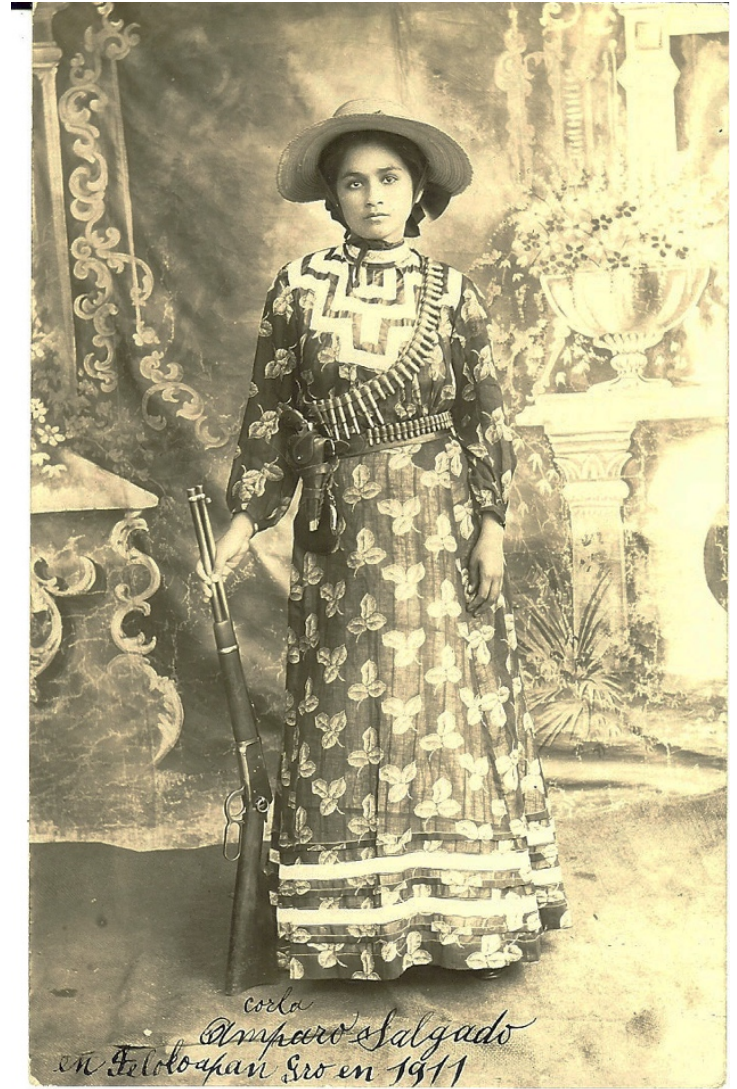

F4. Sara Castrejón. Coronela Amparo Salgado, Teloloapan, abril de 1911. Cortesía de Consuelo Castrejón.

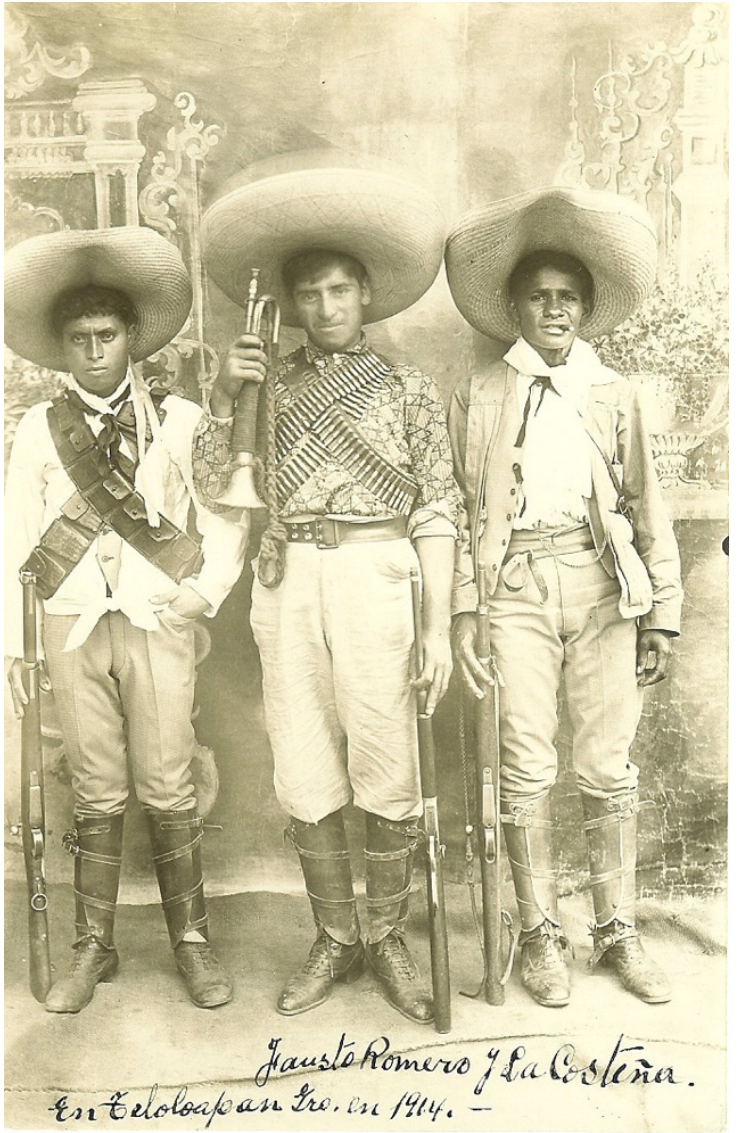

F5. Sara Castrejón. Zapatista Coronela Carmen Robles, "La Costeña", y salgadista Fausto Romero, Teloloapan, 1914. Cortesía de Consuelo Castrejón

Creo que la consciencia de género de Castrejón -el que reconociera y, por lo tanto, representara el papel activo que las mujeres tenían en el conflicto- la llevó a tomar esta imagen compleja y contestataria de Amparo Salgado. Considero este retrato su fotografía más poderosa de la revolución; su fuerza puede derivar de cierto compromiso con el maderismo-salgadismo en sus primeras etapas, parte de la extendida fascinación por el fin de los 35 años de dictadura. Además, ésta no fue la única foto que produjo de combatientes mujeres. La coronel agrarista Carmen Robles, conocida como "La Costeña", fue retratada fumando un puro enrollado a mano como los que se encuentran en la Costa Chica de Guerrero, un enclave negro 
del Pacífico $(\mathrm{F} 5) .{ }^{12}$ La relación de Carmen con otra coronel zapatista también apellidada Robles -Amelia, que se hacía llamar Amelio- no está clara (Cano, 2006, pp. 35-56). La que podría ser una foto excepcional de Sara Castrejón es la de una familia entera armada en el patio de su casa: vemos al padre sosteniendo una espada, a la madre con una daga en la mano, a una muchacha y un muchacho con rifles y hasta a una niña pequeña con una pistola (Villela, 2015, p. 27). Nunca he visto nada parecido a esta foto entre las imágenes de la Revolución Mexicana.

La fotografía ha sido importante para rescatar del olvido tanto a Carmen como Amelia Robles, así como para demostrar que "muchas mujeres tuvieron posiciones de mando en el ejército zapatista" (Cano, 1997, p. 1358). No es fácil saber si las mujeres gozaban de una posición especial en el zapatismo o si estaban más protegidas de los omnipresentes raptos y violaciones que llevaban a cabo todas las fuerzas. Si era así, quizá la ética de la aldea y la participación del intelectual anarquista Antonio Díaz Soto y Gama fueron factores importantes. ${ }^{13} \mathrm{El}$ antropólogo Samuel Villela afirma que el hecho de que campesinos y campesinas trabajan lado a lado dio a las mujeres más espacio en las decisiones y por lo tanto más oportunidades de acceder a posiciones de dirección (Villela, 2009). La académica feminista Eli Bartra difiere fuertemente de esta noción, argumentando que las campesinas son tratadas como ciudadanas de segunda clase, aunque sí cree que la densidad de población y la consecuente ubicuidad de la presencia femenina en las revoluciones del sur puede haber sido un factor importante en su ascenso a posiciones de poder, además de la influencia del pensamiento anarquista (Bartra, 2009). ${ }^{14}$ Por desgracia, la participación de las mujeres en la Revolución Mexicana es un tema poco

12. "La Costeña" aparece en dos otras fotos conocidas: ver Mraz (2010, p. 115) y Poniatowski (1999, p. 61).

13. La historiadora Laura Espejel (2009), experta en el zapatismo, comentó que ha descubierto cartas de padres que se dirigen a Zapata para quejarse de que un soldado u oficial zapatista secuestró a su hija, pues creían que eso deshonraba a la familia. Espejel cree que esas cartas indican la existencia de un "código de valores o principios que formaban parte de la existencia cotidiana de los pequeños pueblos del sur”.

14. También es importante señalar la película pionera La Negra Angustias (Landeta, 1949), sobre otra coronel zapatista de Guerrero, la mulata campesina Angustias (Remedios) Farrera, interpretada por María Elena Marqués con maquillaje negro. Basada en el libro de Francisco Rojas González, la película fue dirigida por Matilde Landeta, una de las primeras directoras mexicanas, quien dio a su película un final distinto al del libro para realzar el papel de la protagonista (Bartra, 2012, pp. 275283). 
explorado. Pero, cuando esa historia se escriba, imagino que la fotografía aportará información valiosa y pistas que puedan seguirse. Castrejón también fotografió a mujeres de otras ocupaciones, como enfermeras y las que posan en retratos.

La participación de los niños en la revolución se ha estudiado incluso menos que la de las mujeres. Sin embargo, en las fotografías son tan omnipresentes como las mujeres, y Castrejón participó retratándolos en su estudio. Pero es importante enfatizar que en México la niñez era (y sigue siendo) muy corta, particularmente para los campesinos, de quienes se esperaba empezaran a trabajar ya desde los ocho años (Alcubierre y Carreño King, 1996, p. 155). Los niños se vieron absorbidos por la revolución por varias razones. Cuando sus tierras eran invadidas por fuerzas enemigas, seguían a sus familias a las campañas, donde los vagones y los campamentos se volvían sus nuevos espacios domésticos. Muchachos adolescentes se unían para escapar de sus familias, por la paga o por la aventura, o porque se sentían atraídos por el carisma de líderes como Pancho Villa; a veces eran obligados, sobre todo por el gobierno huertista. Cumplían diversas funciones: portaban agua, atendían a los caballos, llevaban mensajes, montaban guardias y espiaban. En una fotografía, vemos a dos muchachos -Paulino Santana no podía tener más de quince años- pocos minutos antes de ser ejecutados (F6).

Entre las tareas de Castrejón estaba el fotografiar ejecuciones. Cuando las diferentes facciones llegaban por la noche a pedirle que fotografiara a los que iban a ser fusilados, todas las mujeres se ocultaban en la casa hasta que su hermano, Joaquín, juzgaba que no había peligro de violación. Joaquín siempre la acompañaba, cargando la cámara y el trípode (Castrejón Arriaga, 2012). A veces, Sara fotografiaba a los condenados con antelación, pues sus familias querían conservar los retratos de sus seres queridos como recuerdos. Era una situación en cierto modo parecida a la de los hermanos Cachú, que fotografiaban a revolucionarios colgados en Michoacán a petición de los deudos (Mraz, 2010, pp. 139-140). En otros momentos, los oficiales federales le pedían que fotografiara las ejecuciones para tener evidencia de que habían cumplido sus órdenes. Existen muchas fotografías de ejecuciones durante la 


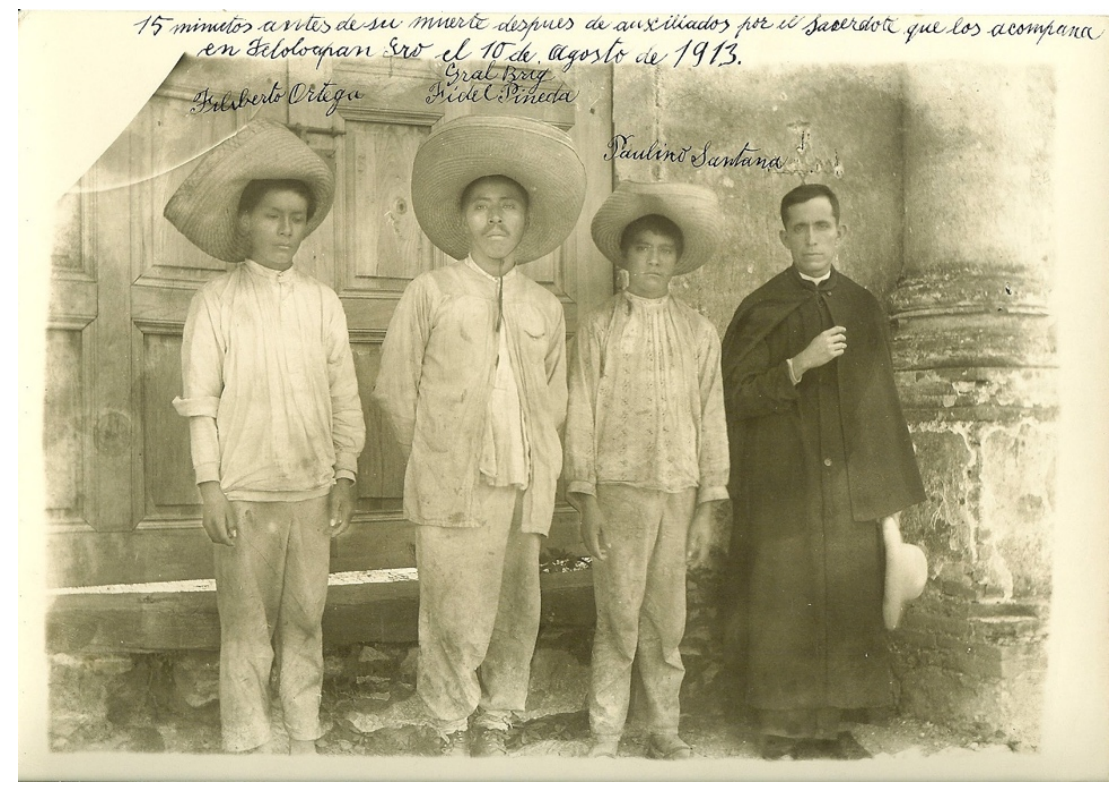

F6. Sara Castrejón. Salgadistas Filiberto Ortega, General Fidel Pineda y Paulino Santana, 15 minutos antes de su fusilamiento, Teloloapan, 10 de agosto de 1913. Cortesía de Consuelo Castrejón.

revolución; algunas muestran individuos esperando su suerte con resignación; otras documentan resistencia por parte de los condenados (Mraz, 2010, pp. 210-212). ¿Fue importante para captar estas desagradables situaciones la empatía que ella, como mujer, llevaba consigo? ¿Cómo se sentía al tomar estas fotos? Nájera Castrejón (2012) lo resume sucintamente: "Ella era una profesional de la fotografía... se veía obligada a ir allá”. Pero, como señaló Consuelo Castrejón Arriaga (2012), sobrina nieta de Sara, "eso a ella le impactaba y decía que eso era algo que nunca se le iba a olvidar, ver eso, fusilamientos". Cualquiera que fueran sus sentimientos, llevó a cabo su labor con destreza, como puede verse en una fotografía donde los individuos que esperaban su ejecución fueron fusilados.

Aunque la mayor parte de su archivo se ha perdido, es evidente que Castrejón siguió fotografiando a lo largo la revolución. ${ }^{15}$ El triunfo de Madero en mayo de 1911 no fue sino el principio de lo que se convertiría en una larga y sangrienta guerra de clases. Las fuerzas sociales que la rebelión maderista había desatado comenzaron a desafiar su limitada visión de lo que el levantamiento significó para él, un rico propietario de tierras, y sus simpatizantes burgueses, en comparación con lo que significó para los

15. Como con todos los fotógrafos de la revolución, estamos lidiando con supervivientes. Como se señala en la nota 6, tras la muerte de Castrejón, su archivo fue saqueado. 
campesinos pobres. Pascual Orozco se alzó en el norte en 1912, y Emiliano Zapata continuó su insistencia armada en el reparto agrario en Morelos, firmando el Plan de Ayala en noviembre de 1911, mientras proclamaba a Madero "inepto, traicionero y tiránico" (Womack, 1968, p. 126). En Guerrero, Jesús Salgado se negó a aceptar la posición de los rancheros liberales dominada por los Figueroa, a quienes Madero apoyó.

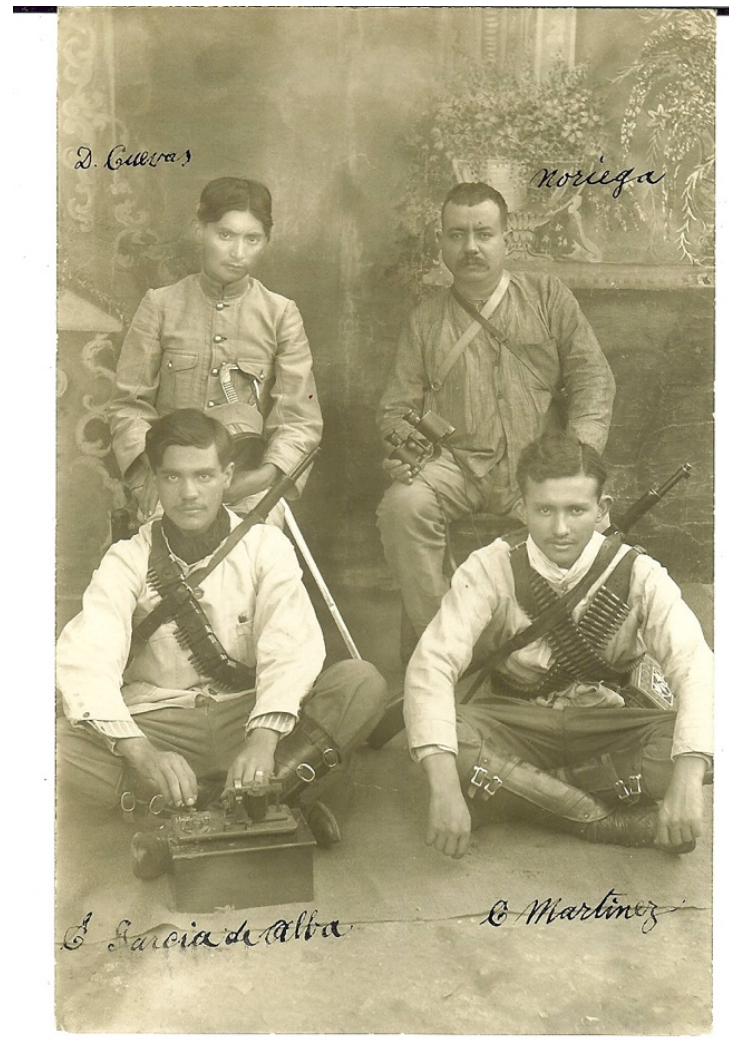

F7. Sara Castrejón. Tropas maderistas ocupando a Teloloapan, 1912. Véanse el equipo que muestran: un radio de campo y binoculares. Cortesía de Consuelo Castrejón.

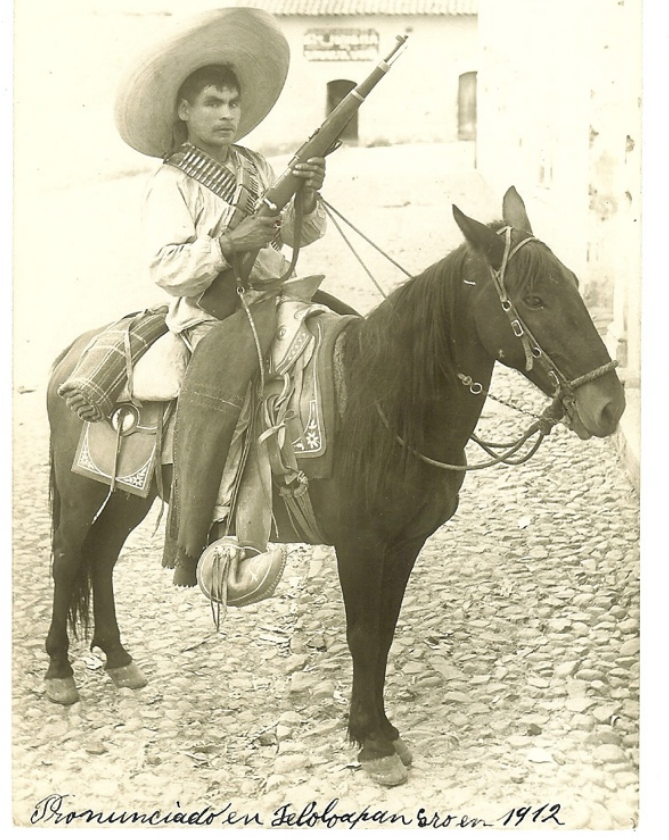

F8. Sara Castrejón. "Pronunciado," un soldado campesino salgadista, Teloloapan, 1912. Cortesía de Consuelo Castrejón.

Como Madero, los Figueroa aspiraban a una solución política, más que social. Afirmó el historiador Alan Knight (1990, vol. 1, p. 17) que "los Figueroa, como otros caciques serranos, buscaban subvertir el orden político, no el social. Querían echar al régimen sediento de poder y centralizador de Díaz y remplazarlo por una forma de caciquismo tradicional, controlado por ellos y sus partidarios". Las tropas maderistas que venían a respaldar los Figueroa estaban mejor equipadas que las salgadistas, como puede apreciarse en la foto con su radio de campo y sus binoculares (F7). Dado que todos 
los maderistas llevaban las mismas armas, uno podía usar las municiones que le sobraran a otro, y si el arma se atascaba podía cambiarla por la de un compañero herido o muerto. Las fotografías de Castrejón nos permiten ver la uniformidad del armamento de las fuerzas maderistas y huertistas que contrasta con la variedad de armas que llevaban los agraristas.

Las fuerzas salgadistas se negaron a rendirse ante el poder abrumador de los maderistas y volvieron a la guerra de guerrillas. Salgado tomó la ciudad el 15 de enero de 1912 (Nájera Castrejón, 1997, p. 72). A los salgadistas se les conocía como "pronunciados" (pues se habían pronunciado por la reforma agraria), y uno de ellos fue retratado fuera del estudio de Castrejón, en una pose que repetirían los combatientes de todas las facciones (F8). Los salgadistas entraron y salieron de Teloloapan a lo largo de 1912-13, pero el golpe de estado de Huerta en 1913 inició una dictadura militar severa y, según sus propias memorias, ejemplar: "No creo que nadie haya establecido un gobierno militar como el mío. Todos los mexicanos fueron militares. Los maestros de escuela, los empleados, los barrenderos, los ministros, los niños, los gobernadores, los secretarios particulares, los diputados, los empleados de todos los ramos, todos fueron militares" (Huerta, citado en del Castillo Troncoso, 2006, pp. 231-232). La manera más fácil de convertir a la gente en militares era mediante las levas. Los soldados descalzos o de huaraches de la costa probablemente fueron forzados a entrar al ejército huertista (F9). Es interesante notar que las fotos de Castrejón de los soldados costeños y otros soldados rasos no llevan los nombres de los fotografiados, mientras que a los oficiales de los dos bandos se les identifican por sus nombres.

Los agraristas y los rancheros unieron fuerzas para combatir a Huerta tal como, a nivel nacional, Zapata y Villa colaboraron con las fuerzas constitucionalistas de Carranza y Obregón. Cuando Teloloapan se volvió un refugio para los zapatistas que huían de la ofensiva huertista en Morelos, más soldados zapatistas y antihuertistas fueron fotografiados (Guzmán Urióstegui, 2002, p. 115). Uno de los líderes agrarios más importantes en la alianza de Zapata y Salgado era Adrián "El Indio" Castrejón, un pariente de Sara que se convirtió en el general más joven de la revolución (y posteriormente en gobernador de Guerrero); todavía era coronel (y apenas había 
salido de la adolescencia) cuando se le tomó esta fotografía (F10). Los Figueroa se aliaron temporalmente con las fuerzas agrarias dirigidas por Salgado y Adrián Castrejón; pero cuando Huerta fue derrocado, se aliaron con los constitucionalistas, y con el tiempo establecerían uno de los cacicazgos más represivos y atrasados del país.

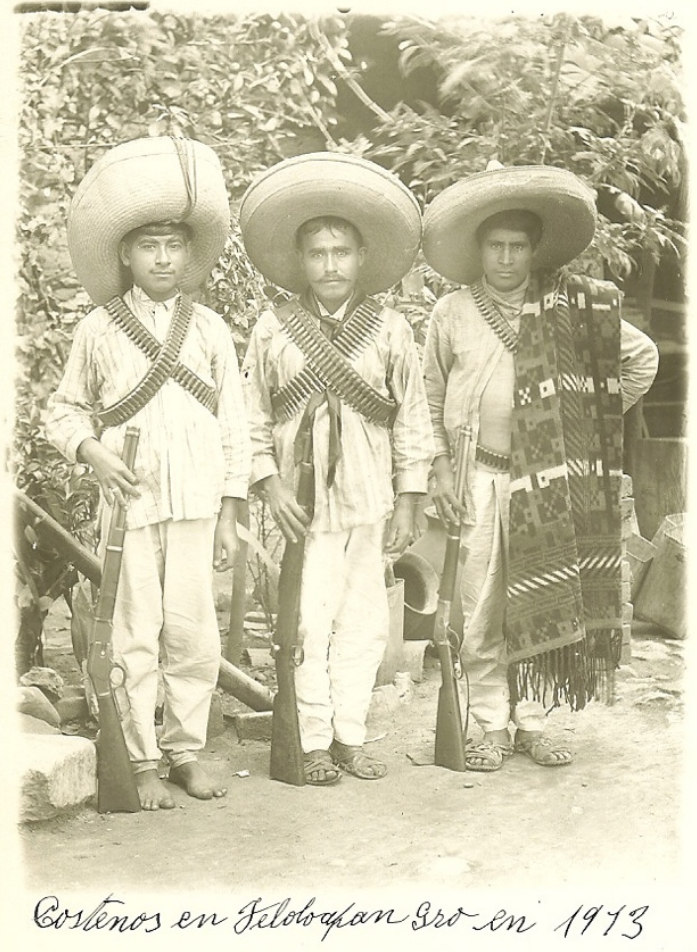

F9. Sara Castrejón. Soldados huertistas de la costa, probablmente como resultado de una leva, un constante durante la dictadura huertista, Teloloapan, 1913. Cortesía de Consuelo Castrejón.

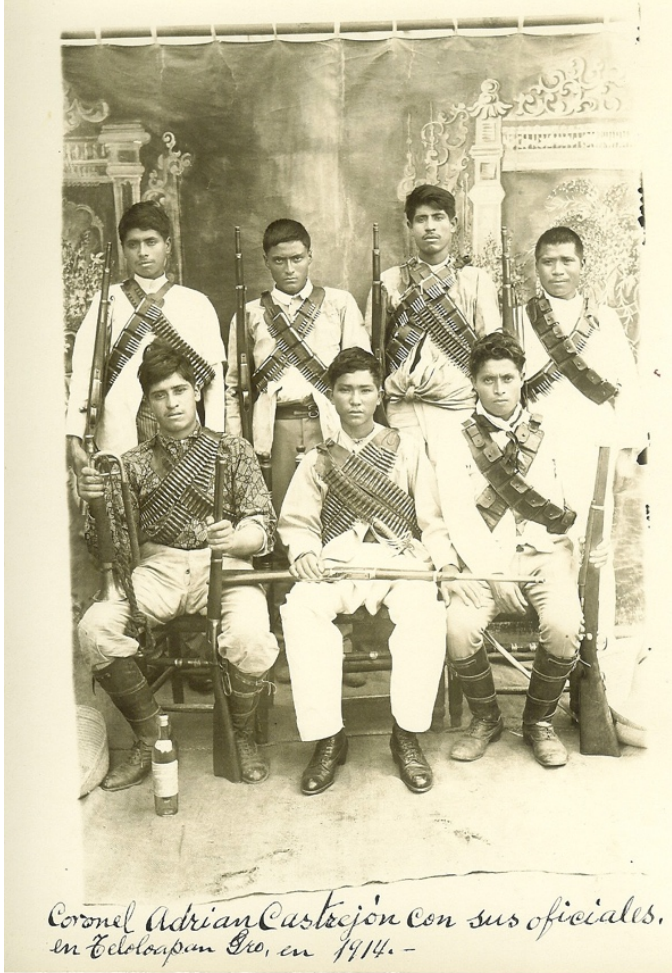

F10. Sara Castrejón. Salgadista Coronel Adrián Castrejón con sus oficiales, Teloloapan, 1914. Cortesía de Consuelo Castrejón.

Para 1915, se hacía cada vez más evidente que las fuerzas constitucionalistas ganarían la guerra contra los más radicales zapatistas y villistas. En Guerrero, eso auguraba la derrota de los salgadistas y demás agraristas. Esto quedó registrado en los sujetos fotográficos de Castrejón que eran ya casi exclusivamente miembros de entidades constitucionalistas y de los Figueroa. Un individuo que aparece en más de una docena de las fotos que se conservan de Castrejón en torno al año 1917 es el teniente coronel Silvestre Castro, conocido como "El Ciruelo", porque venía de un pueblo llamado Ciruelar, en la Costa Grande de Guerrero. Según Consuelo Castrejón 
Arriaga (2012), El Ciruelo solía ir a que lo fotografiaran temprano por la mañana, y casi siempre iba solo. Da a entender que pudo haber sido para Sara algo más que un sujeto fotográfico. Dijo que Castrejón era "muy exigente” tanto en su vida profesional como en su vida privada. Nunca se casó, pues se dice que "no llegó nadie que valiera la pena" (Castrejón Arriaga, 2012). Bien cabe imaginar que no era fácil para una mujer tan fuerte y decidida encontrar un hombre que la dejara ser quien era, aunque es posible que esto fuera una excentricidad de la familia, porque, de siete hijos e hijas, sólo uno se casó.

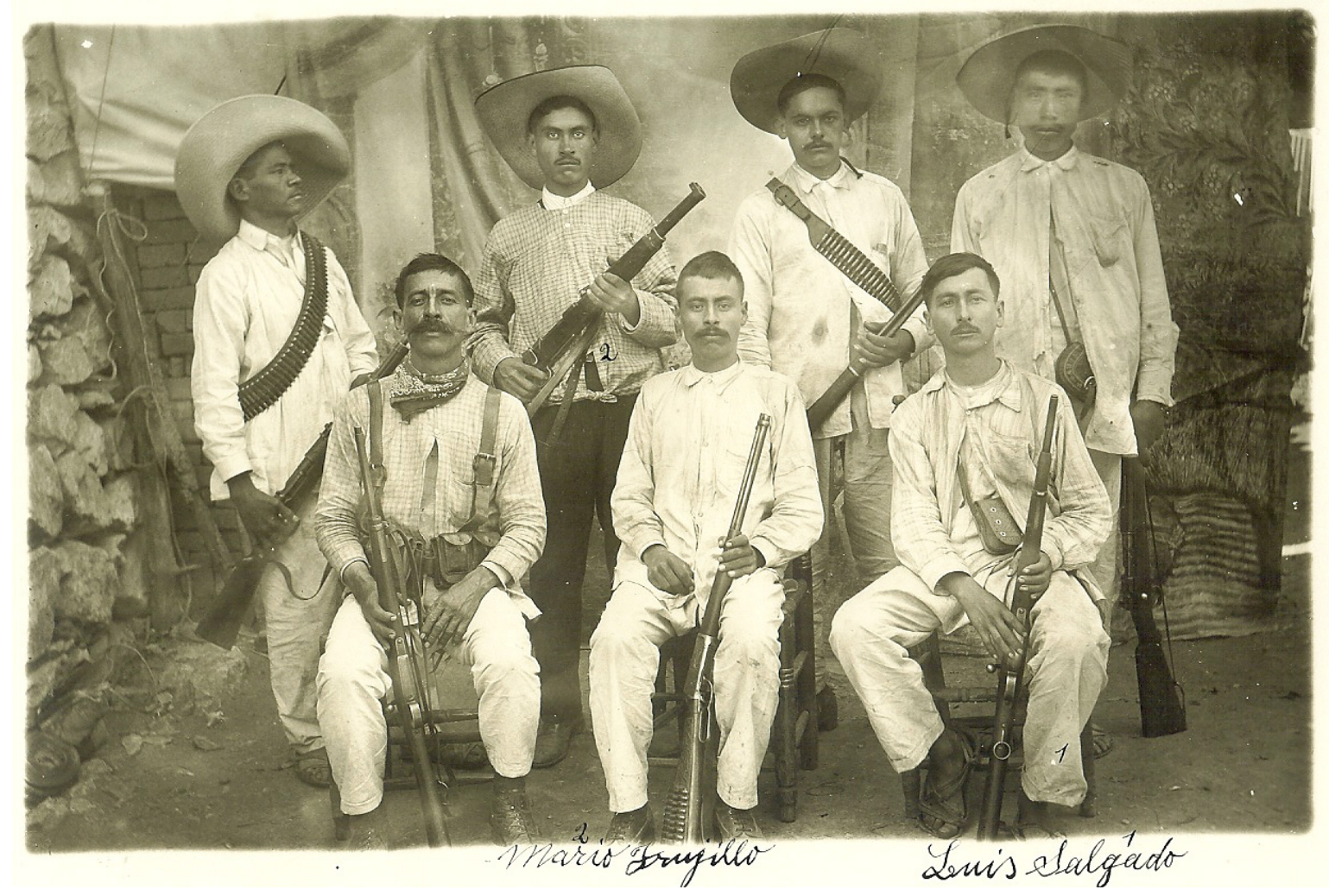

F11. Sara Castrejón. Revolucionarios salgadistas-castrejonistas, entre ellos Luis Salgado y Mario Trujillo, Teloloapan, 1918. Cortesía de Consuelo Castrejón.

Pese a la victoria de los constitucionalistas, el sueño agrarista de una distribución radical de la tierra, la definición de las tierras ejidales como perpetuamente inalienables y la restitución de propiedades comunitarias no murió. Por un lado, muchas de las exigencias zapatistas se incorporaron a la Constitución de 1917. Por otro, tropas como las que comandaba Adrián Castrejón siguieron luchando por sus ideas. Vemos a miembros de las fuerzas de El Indio, armados con todo tipo de armas 
capturadas del enemigo, que se volverían un problema en el combate (F11). También impresiona el modo en que le devuelven la mirada a la cámara, con la excepción del costeño negro, que sin duda ha aprendido la pose de "gran hombre" que mira hacia el futuro.

Sara Castrejón fue una verdadera pionera: fue la única mujer que fotografió a lo largo de toda la Revolución Mexicana. Además, redefinió cómo se retrataba a las mujeres en su lugar natal, ligándolas indisolublemente a la identidad de Teloloapan. Produjo imágenes únicas del Porfiriato y la revolución, llevando a su labor la mirada femenina, representando a su género como un protagonista de la lucha y ofreciendo una empatía hacia los condenados que en cierto modo la hizo distinta de los demás fotógrafos. Como relata Consuelo Castrejón Arriaga (2012):

Fue una mujer que se adelantó su tiempo, que supo manejar su papel de mujer en ese tiempo. Ella nos transmitió eso, de que lo que se quiere, se puede hacer con seguridad, pero siendo una veraz, congruente con su vida, sin vanagloriarse de nada.... Sara era más especial en el sentido de disciplina, de orden. Creo que en la actualidad debe ser un ejemplo Sara Castrejón. Porque las mujeres ahora, como todo es fácil. Conocer a una mujer que luchó puede ser un ejemplo para las mujeres que en la vida van buscando un lugar. Muy orgullosa me siento yo de ella y muy orgullosa de pertenecer a los Castrejón.

Sara Castrejón siguió fotografiando durante los años cincuenta y murió en 1962. El orgullo que le daba ser mujer y que les transmitía a las mujeres que fotografiaba puede verse en su retrato de los años cuarenta de una teloloapense que posa con vestido elegante (F12). Segura de sí misma y de su lugar en la sociedad, la mujer le devuelve la mirada a la cámara y participa en el acto fotográfico tan plenamente como la fotógrafa. 


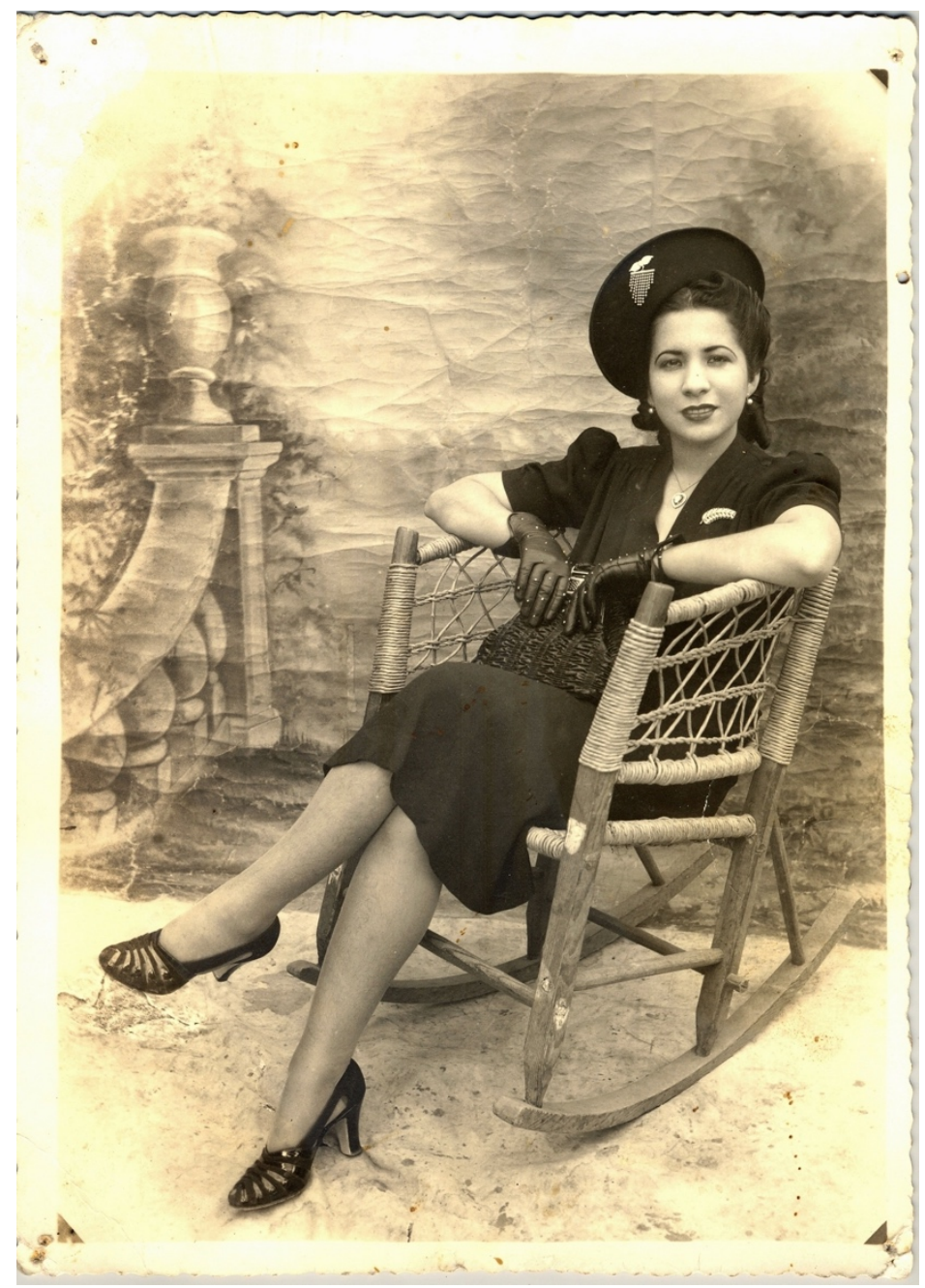

F12. Sara Castrejón. Retrato de mujer. Teloloapan, Guerrero, ca. 1945. Cortesía de Samuel Villela

\section{Referencias bibliográficas}

Alcubierre, B., y Carreño King, T. (1996). Los niños villistas: Una mirada a la historia de la infancia en México, 1900-1920. Ciudad de México: Secretaría de Gobernación/INHERM.

Batchen, G. (Ed.). (2000). Vernacular Photographies: History of Photography, número especial, 24 (3): 262-271.

Bartra, E. (2009). Entrevista a la feminista Eli Bartra/Entrevistador John Mraz. Ciudad de México.

Bartra, E. (2012). How Black is La Negra Angustias? Third Text (116), 275-83.

Bartra, E. (1996). Por las inmediaciones de la mujer y el retrato fotográfico: Natalie Baquedano y Lucero González. Política y Cultura (6), 85-109. 
Berumen, M.Á. (2005). 1911: La batalla de Ciudad Juárez/II. Las imágenes. Ciudad Juárez: Cuadro por Cuadro.

Cano, G. (2010). Se llamaba Elena Arizmendi. Ciudad de México: Tusquets.

Cano, G. (1997). Soldaderas and Coronelas. En M. S. Werner (Ed.), Encyclopedia of Mexico: History, Society \& Culture, vol. 1, (pp. 1357-1360). Chicago: Fitzroy Dearborn.

Cano, G. (2006). Unconcealable Realities of Desire: Amelio Robles's (Transgender) Masculinity in the Mexican Revolution. En J. Olcott, M. K. Vaughan y G. Cano (Eds.), Sex in Revolution: Gender, Politics, and Power in Modern Mexico (pp. 35-56). Durham: Duke University Press.

Carmichael, J. (1989). First World War Photography. Londres: Routledge.

Castrejón Arriaga, C. (2012). Entrevista a la señora Consuelo Castrejón Arriaga/Entrevistador: Samuel Villela. Acapulco: Guerrero.

Córdova, C. (2014). Entrevista al fotohistoriador Carlos Córdova/Entrevistador John Mraz. Ciudad de México.

Debroise, O. (1994). Fuga mexicana: Un recorrido por la fotografía en México. Ciudad de México: CONACULTA.

Del Castillo Troncoso, A. (2006). Conceptos, imágenes y representaciones de la niñez en la ciudad de México, 1880-1920. Ciudad de México: El Colegio de México-Instituto Mora, 2006.

Del Castillo Troncoso, A. (2005). La historia de la fotografía en México, 1890-1920: La diversidad de los usos de la imagen. En E. C. García Krinsky (Ed.), Imaginarios y fotografía en México, 1839-1970 (pp.58-117). Barcelona: Lunwerg.

Espejel, L. (2009). Entrevista a la historiadora Laura Espejel/Entrevistador: John Mraz. Ciudad de México.

Fernández Tejedo, I. (1994). Recuerdo de México: La tarjeta postal mexicana 18821930. Ciudad de México: Banobras.

Figueroa, L. (2004) Entrevista a la señora Lucila Figueroa/Entrevistador: Samuel Villela, Telolopan, Guerrero.

García Krinsky, E.C. (2012). Mujeres detrás de la lente: 100 años de creación fotográfica en México, 1910-2010. Ciudad de México. CONACULTA, 2012.

Gautreau, M. (2007). La Ilustración Semanal y el Archivo Casasola. Cuicuilco, 14 (41), 113-142.

González, A.J. (2016). Fotógrafo de Guerra. Fotografía de Guerra en España, 18591939. Córdoba: Diputación de Córdoba.

Gould, L., y Greffe, R. (1977). Photojournalist: The Career of Jimmy Hare. Austin: University of Texas Press.

Guzmán, M. L. (1978 [1928]). El águila y la serpiente. Ciudad de México: Colección Málaga. 
Guzmán Urióstegui, J. (2002). Teloloapan entre el tezcal y la sal. Teloloapan: Ayuntamiento Municipal Constitucional de Teloloapan.

Hare, J. (1940). Forward. En C. Carnes, Jimmy Hare: News Photographer; Half a Century with a Camera (pp. vii-viii). Nueva York; Macmillan.

Hart, J.M. (1987). Revolutionary Mexico: The Coming and Process of the Mexican Revolution. Berkeley: University of California Press.

Jacobs, I. (1982). Ranchero Revolt: The Mexican Revolution in Guerrero. Austin: University of Texas Press.

Jiménez, B. y Villela, S. (1998). Los Salmerón: Un siglo de fotografía en Guerrero, Ciudad de México: INAH.

Knight, A. (1990). Porfirians, Liberals, and Peasants, vol. 1 de The Mexican Revolution. Lincoln: University of Nebraska Press.

Knight, A. (1990). Counter-revolution and Reconstruction, vol. 2, The Mexican Revolution. Lincoln: University of Nebraska Press.

Knightley, P. (1975). The First Casualty: The War Correspondent as Hero, Propagandist, and Myth Maker from the Crimea to Vietnam. Nueva York: Harcourt Brace Jovanovich.

Lambert, D. (1994). Regional Core-Periphery Imbalance: The Case of Guerrero, Mexico, since 1821, Yearbook: Conference of Latin Americanist Geographers, (20), 59-71.

Landeta, M. (1950). La Negra Angustias. México: TACMA.

López Victoria, J. M. (1985). Historia de la revolución en Guerrero, vol. 1. Chilpancingo: Gobierno del Estado de Guerrero.

Martínez, L. (2000). Antes que los dulces de platón, las placas de colodión. Alquimia (8), 32-33.

Martínez, L. (2015). Mujeres fotógrafas hacen trabajo a domicilio. Alquimia (53), 3437.

Meyer, M. C., y W. L. Sherman. (1987). The Course of Mexican History. New York: Oxford University Press

Moeller, S. (1989). Shooting War: Photography and the American Experience of Combat. Nueva York: Basic Books.

Monroy Nasr, R. (2015). Precursoras en la imagen fotográfica: Alquimia, número especial, (53), 14-15.

Mraz, J. (en prensa). Fotohistorias de la Revolución Mexicana. Historias.

Mraz, J. (2010). Fotografiar la Revolución Mexicana: compromisos e íconos. Ciudad de México: INAH.

Mraz, J. (2012). Photographing the Mexican Revolution: Commitments, Testimonies, Icons. Austin: University of Texas Press. 
Nájera Castrejón, F. (1997). Gral. Jesús H. Salgado, indómito luchador. Taxco: Fotopress Editores.

Nájera Castrejón, F. (2012). Entrevista al historiador Francisco Nájera Castrejón/Entrevistador: Samuel Villela. Telolopan: Guerrero.

Notices, OHS Research Library. (2007). Oregon Historical Society 108, (1), 157.

Ocampo M., Joaquín. (2018). Entrevista al señor Joaquín Ocampo M./Entrevistador: Samuel Villela.

Poniatowska, E. (1999). Las soldaderas. Ciudad de México: Era/CONACULTA/INAH.

Robledo Martínez, J. (2014). Episodios fotográficos de la toma de Zacatecas, 19131914. Zacatecas: Fototeca de Zacatecas "Pedro Valtierra".

Rodríguez, J.A. (2012). Fotógrafas en México, 1872-196o. Madrid: Turner.

Sadie Kneller Miller. (2015). Wikipedia, s.v., consultado el 3 de octubre. https://en.wikipedia.org/wiki/Sadie_Kneller_Miller.

Sartre, J-P. (1949). For Whom Does One Write? En Literature and Existentialism (pp. 67-160), trad. Bernard Frechtman. Nueva York: Citadel Press.

Tarjetas postales (1903). El Mundo: Semanario ilustrado, 5 de julio, 13.

Vanderwood, P., y Samponaro, F. (1988). Border Fury: A Picture Postcard Record of Mexico's Revolution and U.S. War Preparedness, 1910-1917. Albuquerque: University of New Mexico Press.

Villela, S. (2009). Entrevista al fotohistoriador Samuel Villela/Entrevistador John Mraz. Ciudad de México.

Villela, S. (2010). Sara Castrejón: Fotógrafa de la revolución. Ciudad de México: INAH.

Villela, S. (2015). Sara Castrejón. Fotógrafa de Teloloapan. Alquimia (53), 20-33.

Womack, J. (1968). Zapata and the Mexican Revolution. Nueva York: Alfred A. Knopf. 